\title{
Experimentacion y Optimizacion Conjunta de la DisRupcion Celular de Microalgas y Extraccion Soxhletde Aceite Para Alimentacion y Biocombustibles
}

\author{
Experimental and Optimizationof Joint Microalgae Cell \\ DisRuPtion and Soxhlet Lipid Extraction for Food and Fuel
}

\section{Ángel D. González Delgado', Yeimmy Y. Peralta Ruiz², Luz S. Córdoba³ Lina M. López ${ }^{4}$, Viatcheslav Kafarov ${ }^{5}$}

\author{
${ }^{1}$ University of Cartagena, Chemical Engineering Department, Cartagena, Colombia, \\ andagonegmail.com
}

${ }^{2}$ San Buenaventura University, Chemical Engineering Department, Cartagena, Colombia, yeimmy.peralta@usbctg.edu.co

3,4,5Industrial University of Santander, Center for Sustainable Development in Industry and Energy, Bucaramanga, Colombia,

cisyc@uis.edu.co

\section{RESUMEN}

La producción de biocombustibles y bioproductos utilizando microalgas puede realizarse con tratamientos térmicos para producir biocrudo, o mediante la extracción y transformación de metabolitos específicos. Esta última alternativa incluye las etapas de cultivo, cosecha, secado, extracción de lípidos y purificación o transformación de los mismos. La factibilidad técnica y económica de la obtención de bioproductos derivados del aceite de microalgas depende en gran medida de la eficiencia de extracción de los lípidos. El objetivo principal de este trabajo es establecer una metodología para la disrupción celular y extracción soxhlet de aceite de microalgas, y determinar su efectividad en tres cepas nativas; Amphiprora, Desmodesmus y Tetraselmis. Se evaluó el efecto de distintos métodos de disrupción celular como MSA, MHA, HA4M Fast, y HA0.5M Slow, solventes como hexano, ciclohexano y metanol, y tiempos de extracción de 4,6 y 8 horas, sobre la cantidad de aceite extraído. La mayor eficiencia de extracción se obtuvo utilizando disrupción celular MSA. El mejor solvente fue hexano y el mejor tiempo de extracción fue de 8 horas.

Palabras clave: biodiesel a partir de microalgas, disrupción celular, extracción soxhlet. 


\section{ABSTRACT}

Biofuels and bioproducts production from microalgae can be made with thermal treatments for biocrude production or by metabolite extraction, this pathway includes the stages of growing, harvesting, drying, lipid extraction and purification or transformation of oil. The technical and economic feasibility of lipid-based bioproduct production depends in a great way of the oil extraction efficiency. The main objective of this work is to establish a methodology for native microalgae oil extraction based on bothsoxhlet extraction and cell disruption, and determine its effectiveness in threegenera of native microalgae; Amphiprora, Desmodesmus and Tetraselmis.

The effect of different cell disruption methods as MSA, MHA, HA4M Fast, and HA0.5M Slow, solvents as hexane, cyclohexane and ethanol, and extraction times of 4, 6 and 8 hours, on the oil yield were evaluated. The highest extraction efficiency was achieved by employing the MSAfor cell disruption, the best solvent was hexane and the extraction time was eight hours.

Keywords: biodiesel from microalgae, cell disruption, soxhlet extraction.

\section{Introduction}

Biofuels production has been growing worldwide in recent years. Increasing fuel demand, limited reserves, high crude oil prices and the need to mitigate environmental pollution associated with consumption of fossil fuels have boosted the research and development for clean and renewable fuels. As part of an effort to find a solution, scientists and engineers have been given the task to develop a more efficient and sustainable resource. This has led to the development of biofuels, within them, the third generation biofuels as biodiesel from microalgae[1]because its main feedstock is agricultural product. Increasing biofuel production therefore is going to have an impact on world agricultural commodity prices and food security. The purpose of this study is to conduct an economic analysis of increasing biofuel production on food security. The own price elasticities of supply equations in the long-term are the key to deciding agricultural commodity price adjustments as a result of an increase in biofuel production. Biofuel production may have a negative impact on food security, but on the other hand they can create opportunities for agricultural development. It is critical to understand that own price elasticity of feedstock supply is a key factor in deciding how biofuel development can contribute agricultural development. Policy makers should recognize the importance of the price elasticity of feedstock supply when they promote biofuel programs and select feedstock to contribute to agricultural development.", "author" : [ \{ "dropping-particle" : "', "family” : "Koizumi”, "given” : “Tatsuji”, "non-dropping-particle" : “", "parsenames" : false, "suffix" : "” \} ], "container-title" : "Renewable and Sustainable Energy Reviews", "id" : "ITEM-1", "issued" : \{ "date-parts" : [ [ "2015", "12" ] ] \}, "page" : "829-841", "title" : "Biofuels and food security", "type" : "article-journal", "volume" : "52" \}, "uris" : [ "http://www.mendeley.com/ documents/?uuid=c699d19e-a3a9-4a4c-a9635cb7f9efe671" ] \} ], "mendeley" : \{ "formattedCitation" : "[1]”, "plainTextFormattedCitation” : "[1]”, "previouslyFormattedCitation" : "[1]" \}, "properties" : \{ "notelndex" : 0 \}, "schema" : "https://github. com/citation-style-language/schema/raw/master/ csl-citation.json" \}. It is a promising alternative for supply the global demand of fossil derived fuels. Microalgae have been suggested as very good option for fuel production its advantages includes higher photosynthetic efficiency, higher biomass production and faster growth compared to other 
energy crops. In addition, the most important competitive advantage of the use of biodiesel from microalgae, is oil yields per unit area considerably higher than those obtained with oil crops[2], [3].

The efficiency of biodiesel production chain depends in a great way of the oil extraction efficiency.

Therefore, the research developed by authorsis focused in this stage of the process. In the present study, the main objective is to establish a methodology for native microalgae oil extraction in a laboratory scale using a procedure based on both Soxhlet extraction and cell disruption, and determine its effectiveness in three genera of native microalgae; Amphiprora, Desmodesmus and Tetraselmis. During the development of this methodology, the effects of different cell disruption methods (methanol- sulfuric acid, methanol- hydrochloric acid, hydrochloric acid $4 \mathrm{~mol} \mathrm{~L}^{-1}, 1 \mathrm{~min}$ and hydrochloric acid $0.5 \mathrm{~mol} \mathrm{~L}^{-1}, 30 \mathrm{~min}$ ), solvents (hexane, cyclohexane and ethanol) and extraction times (4, 6 and 8 hours) on the oil yield were evaluated. The best experimental conditions were selected in order to increase the extraction efficiency and take advantage of the results found to route future studies focused on develop a sustainable chain for biodiesel production from native microalgae.

\section{EXPERIMENTAL}

\section{A. Raw material, reagents and equipment}

As raw material for extraction three genera of microalgae were used: Amphiprora, Desmodesmusy Tetraselmiswith a lipid content of $12 \%$, $10.9 \%$ and $12.7 \%$ respectively. These microalgae were provided by the Corporation Morrosquillo Institute (Punta Bolívar, Colombia). The lipid content for each sample was provided by Colombian Petroleum Institute (ICP-ECOPETROL). The reagents used for experimental development were hexane $98.5(\% \mathrm{w} / \mathrm{v})$ absolute ethyl alcohol anhydrous $99.9(\% \mathrm{w} / \mathrm{v})$, cyclohexane $99.0(\% \mathrm{w} / \mathrm{v})$, sulfuric acid $97.0(\% \mathrm{w} / \mathrm{v})$, hydrochloric acid fuming $37.0(\% \mathrm{w} / \mathrm{v})$ and methanol $99.9(\% \mathrm{w} / \mathrm{v})$. Also, distilled water was used in the preparation of the solutions and washing processes. In addition, Soxhlet equipment (Soxhlet extractor with 45/50 outer/upper and 24/40 lower/inner joint, for $250 \mathrm{ml}$ capacity) was used.

\section{B. Procedure}

Procedure was divided into two parts, the method of cell disruption and Soxhlet extraction:

1) Method of cell disruption. For this step,all raw materials supplied were dried in a convection digital oven (make WTC binder) at $105{ }^{\circ} \mathrm{C}$ for 4 hours, based on the standard NREL/TP-51042621, and then, the sample was homogenized. After, biomass was subjected to the different cell disruption methods described below.

- Organosolv pretreatment methanol-sulfuric acid (MSA): According to the procedure outlined in [4].

- Organosolv pretreatment methanol-hydrochloric acid (MHA): According to procedure adapted from[5].

- Hydrochloric acid 4 mol L-1, 1 min (HA4M Fast): Each $5 \mathrm{~g}$ of dry biomass was treated with 50 $\mathrm{ml}$ of distilled water and $2.5 \mathrm{ml}$ of hydrochloric acid $4 \mathrm{~mol} \mathrm{~L}^{-1}$. Finally the mixture is stirred for 1 minute at $500 \mathrm{rpm}$.

- Hydrochloric acid $0.5 \mathrm{~mol} \mathrm{~L}^{-1}, 30 \mathrm{~min}$ (HA0.5M Slow):According to the procedure reported in[6].

After that, the treated biomass was separated from the liquid phase using vacuum filtration. The solid phaseretained in the filter was washed repeatedly with distilled water to remove disruptor agent. Finally, biomass was again subjected to a drying process in an oven at $105^{\circ} \mathrm{C}$ for 4 hours. Then, this dry biomass was used forSoxhletextraction to evaluate the efficiency of cell disruption methods.

2) Soxhlet extraction. Soxhlet extraction method was adapted to obtain the oil content in three 
genera of native microalgae. Each experiment was performed with 5 grams of dry treated biomass, using three solvents (hexane, cyclohexane and ethanol) and different extraction times (4, 6 and 8 hours). During Soxhlet extraction, the amount of biomass and the ratio biomass/solvent were kept constant. After extraction, extract-solvent mixture was filtered, distilled and the remnant solvent was evaporated. Total lipids were also quantified gravimetrically[7]. The oil yield and extraction efficiency were calculated using Equations 1 and 2 respectively, where $m_{\text {lipid extracted }}$ is the weight of lipid extracted $(\mathrm{g}), \mathrm{m}_{\text {sample }}$ is the sample weight $(\mathrm{g})$, $A_{L}$ is the oil yield obtained with equation $1(\%)$, and $A_{B}$ is the percentage of lipid content of the initial biomass (\%).Each test was repeated three times.
Oil yield $(\%)=\frac{\mathrm{m}_{\text {lipid extracted }}}{\mathrm{m}_{\text {sample }}} * 100$

Extraction efficiency $(\%)=\frac{A_{L}}{A_{B}} * 100$

\section{Methodology developed}

The methodology was developed in three steps and these phases are shown in Figure 1. In the first and second steps were selected experimental conditions to obtain the highest amount of lipid extracted, and the third step was determined the fatty acids profiles of extracts obtained.
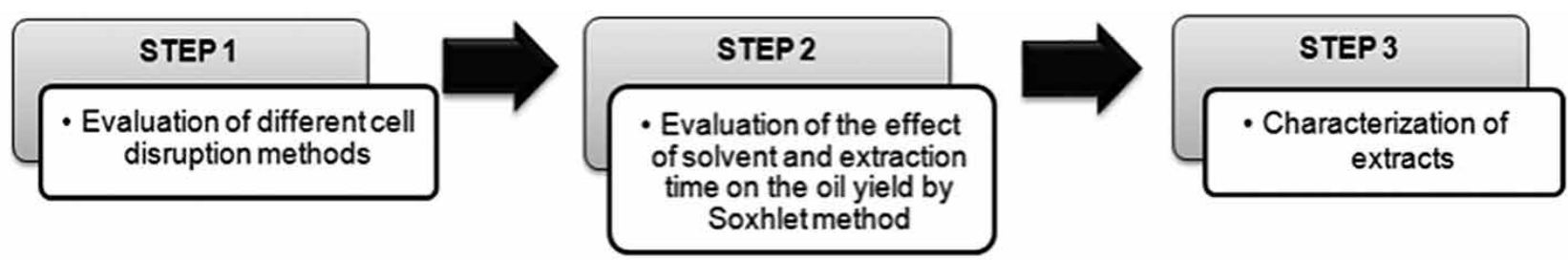

Phase 1:
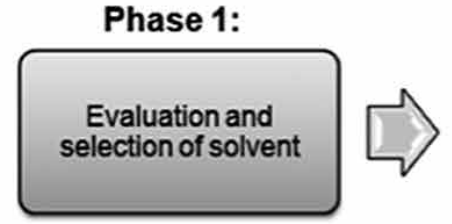

Phase 2:
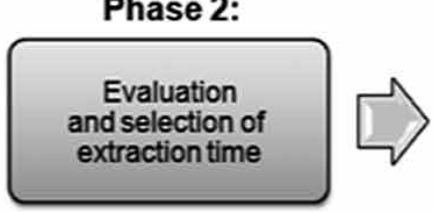

Phase 3:

Implementation of the

best conditions for

other microalgae

genera

Fig. 1 Stepsofthemethodology developed.

In the first step was evaluated the effect of different cell disruption methods (methanol-sulfuric acid, methanol-hydrochloric acid, hydrochloric acid $4 \mathrm{~mol} \mathrm{~L}^{-1}, 1 \mathrm{~min}$, and hydrochloric acid 0.5 mol L-1 $30 \mathrm{~min}$ ) on the oil yield. At this step was used the microalgae Amphiprora sp., eight hours of extraction time and solvent hexane.

After selecting the best treatment for cell disruption according to the oil yield, in the next step was evaluated the effect of solvents and extraction time on the process efficiency. The second step was divided into three phases:

During the first phase were evaluated three solvents; hexane, cyclohexane and ethanol.
These solvents were chosen taking into account their low boiling point, costs, safety factors and toxicity. In the next phase, after selecting the cell disruption method and the solvent for lipid

extraction, the extraction time was evaluated, using values of 4,6 and 8 hoursbased on literature review[8]-[10].In the final phase, the best experimental conditions for the oil yield were applied to the three genera studied. Besides, the third step was the characterization of extracts obtained in order to determine of the fatty acid profile. This characterization was made by the Colombian Petroleum Institute by gas chromatography using an Agilent 7890 GC with FID detector (flame ionization) and DB 5Ht column of 15 meters. 


\section{Results and Discussion}

\section{A. Effect of cell disruption method.}

Figure 2 shows that the methanol-sulfuric acid method provides the highest oil yield $(6.8 \%)$ compared with the other three methods performed. In addition, when methanol- sulfuric acid method was used, the oil yield was increased three times in comparison with the control. This difference can be attributed by the degree of hydrolysis of the cellulosic cell wall components of microalgae according to each disruptor agent and operation conditions of treatment. Then, the lipids are exposed to higher or lower proportion to the solvent extraction and the oil yield is affected.

Respect to the efficiency of the extraction process, Table 1 shows that when MSA method is used, an efficiency of $56.5 \%$ was reached.

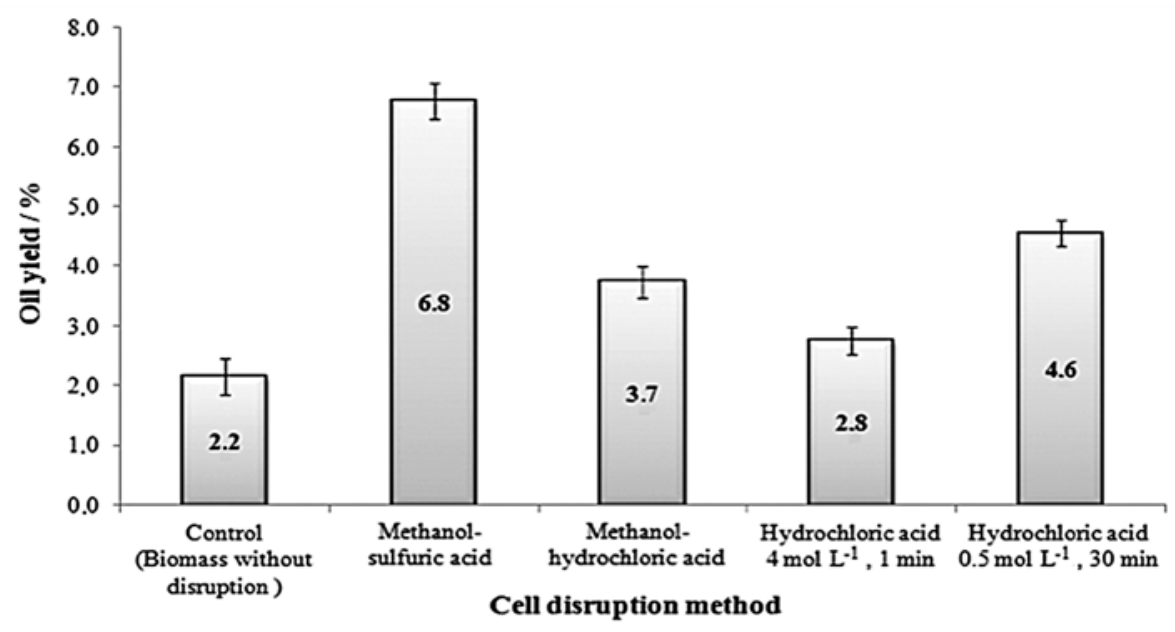

Fig. 2 Effect of different cell disruption methods on the oil yield for Amphiprora sp.

TABLE 1.

Extraction Efficiency In Relation To The Cell Disruption Method Used

\begin{tabular}{|c|c|c|}
\hline Cell disruption method & Extraction efficiency (\%) & Standard deviations \\
\hline Control & 18.0 & 2.4947 \\
\hline MSA & 56.5 & 2.5495 \\
\hline MHA & 31.1 & 2.1928 \\
\hline HA4M Fast & 23.0 & 1.9918 \\
\hline HA0.5M Slow & 37.9 & 1.7802 \\
\hline
\end{tabular}

\section{B. Solvent Selection}

By using hexane, cyclohexane and ethanol as solvents in extraction process, it was shown that the hexane presents higher loss of solvent. However, as evidenced in Figure 3, this solvent produced the greatest oil yield $(6.8 \%)$ relative to cyclohexane (3.2\%) and ethanol (2.3\%). It is also the cheapest solvent of the three tested, also is selective to neutral lipids and commonly used in solvent extraction processes chemicals[11], [12] namely bio-derived solvents, are a type of green solvent that have attracted intensive investigations in recent years because of their advantages over conventional VOCs, such as low toxicity, biodegradability and renewability. This review aims to summarize the use of bio-derived solvents in 
solvent extraction applications, with special emphasis given to utilization of biodiesels and terpenes. Compared with the conventional VOCs, the overall performance of these bio-derived solvents is comparable in terms of extraction yields and selectivity for natural product extraction and no difference was found for metal extraction. To date most researchers have focused on laboratory scale thermodynamics studies. Future work is required to develop and test new bio-derived solvents and understand the kinetic performance as well as solvent extraction pilot plant studies.", "author" : [ \{ "dropping-particle" : "”, "family" : "Li”, "given" : "Zheng", "non-dropping-particle" : “”, "parse-names" : false, "suffix" : "” \}, \{ "droppingparticle" : "”, "family" : "Smith", "given" : "Kathryn H.”, "non-dropping-particle” : “", "parse-names” : false, "suffix" : "” \}, \{ "dropping-particle" : "”, "family" : "Stevens", "given" : "Geoffrey W.", "nondropping-particle" : "”, "parse-names" : false, "suffix" : "” \} ], "container-title" : "Chinese Journal of Chemical Engineering", “id" : "ITEM-1", "issued" : \{ "date-parts" : [ [ "2015", "8" ] ] \}, "title" : "The use of environmentally sustainable bio-derived solvents in solvent extraction applicationslu2014a review", "type" : "article-journal" \}, "uris" : [ "http:// www.mendeley.com/documents/?uuid=4f204747e898-4dd8-9cf8-35d17c1b0821" ] \}, \{ "id" : “ITEM-2", “itemData" : \{ “DOI” : “10.1016/j. jchromb.2013.10.016", “ISSN" : “1873-376X", "PMID" : "24239934", "abstract" : "A method was developed to analyze neutral lipids through the use of three triglycerides, four free fatty acids, six di- and four mono-glycerides standards by high performance liquid chromatography (HPLC.

Besides, when performing the extraction with cyclohexane was obtained the second highest oil yield $(3.2 \%)$, but this is the solvent most expensive of the three solvents studied. Ethanol is known to be a good solvent for extraction, but its selectivity towards the lipids is relatively low compared with hexane and cyclohexane, and it is necessary to perform a purification process (e.g. treating the crude extract with non-polar solvents) to obtain the extracts. The solvent ethanol had the lowest oil yield (2.3\%).

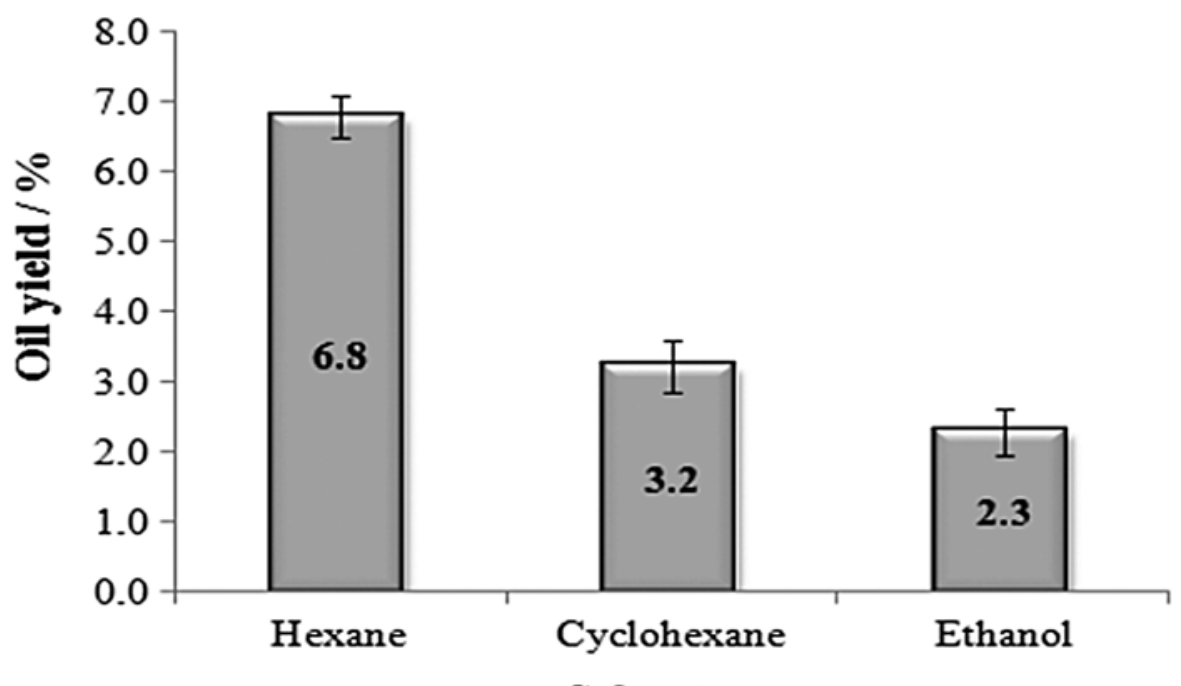

Solvent

Fig. 3 Oil yield with different solvents.

Also, as shown in Table 2 with the use of hexane was achieved, the highest extraction efficiency $(56.5 \%)$ is reached, and solvent hexane shown higher reproducibility of the data according to the standard deviation calculated. 
TABLE 2.

Effect of Solvent on Extraction Efficiency

\begin{tabular}{l|c|c|}
\multicolumn{1}{c|}{ Solvents } & $\begin{array}{c}\text { Extraction } \\
\text { efficiency(\%) }\end{array}$ & $\begin{array}{c}\text { Standard } \\
\text { deviations }\end{array}$ \\
\hline Hexane & 56.5 & 2.5495 \\
\hline Cyclohexane & 26.9 & 3.0353 \\
\hline Ethanol & 19.3 & 2.7426 \\
\hline
\end{tabular}

\section{Effect of extraction time}

Effect of extraction time is observed clearly in Figure 4, when the contact time between solvent and biomass was increased, there was a significant impact on increasing the oil yield, because it promotes the mass transfer of lipid components into the solvent, reaching a higher oil yield (5.8\%) when the sample was extracted for eight hours and with an increasing trend for higher times. In the same way when compared the results with and without cell disruption method, there was an increase of more than five times in the oil yield, for all operation times evaluated.
Furthermore, the extraction time of eight hours produced the best extraction efficiency of $53.6 \%$ as reported in Table 3.

When the best experimental conditions according to the higher oil yield (MSA, hexane solvent and 8 hours of operation time) were applied, results obtained were the shown in Figure 5 for the three genera studied. These results confirm the advantage of applying a cell disruption method before extraction process, it can achieve significant increases in the oil yield for biomass without disruption, and increments of three, five and twelve times oil yield for genera Amphiprora, Desmodesmus and Tetraselmis respectively.

Also as shown in Table 4, for all genera of microalgae was obtained a superior process efficiency to $50 \%$ using the best conditions of the variables analyzed, getting the highest value $57.6 \%$ for the genus Tetraselmis.

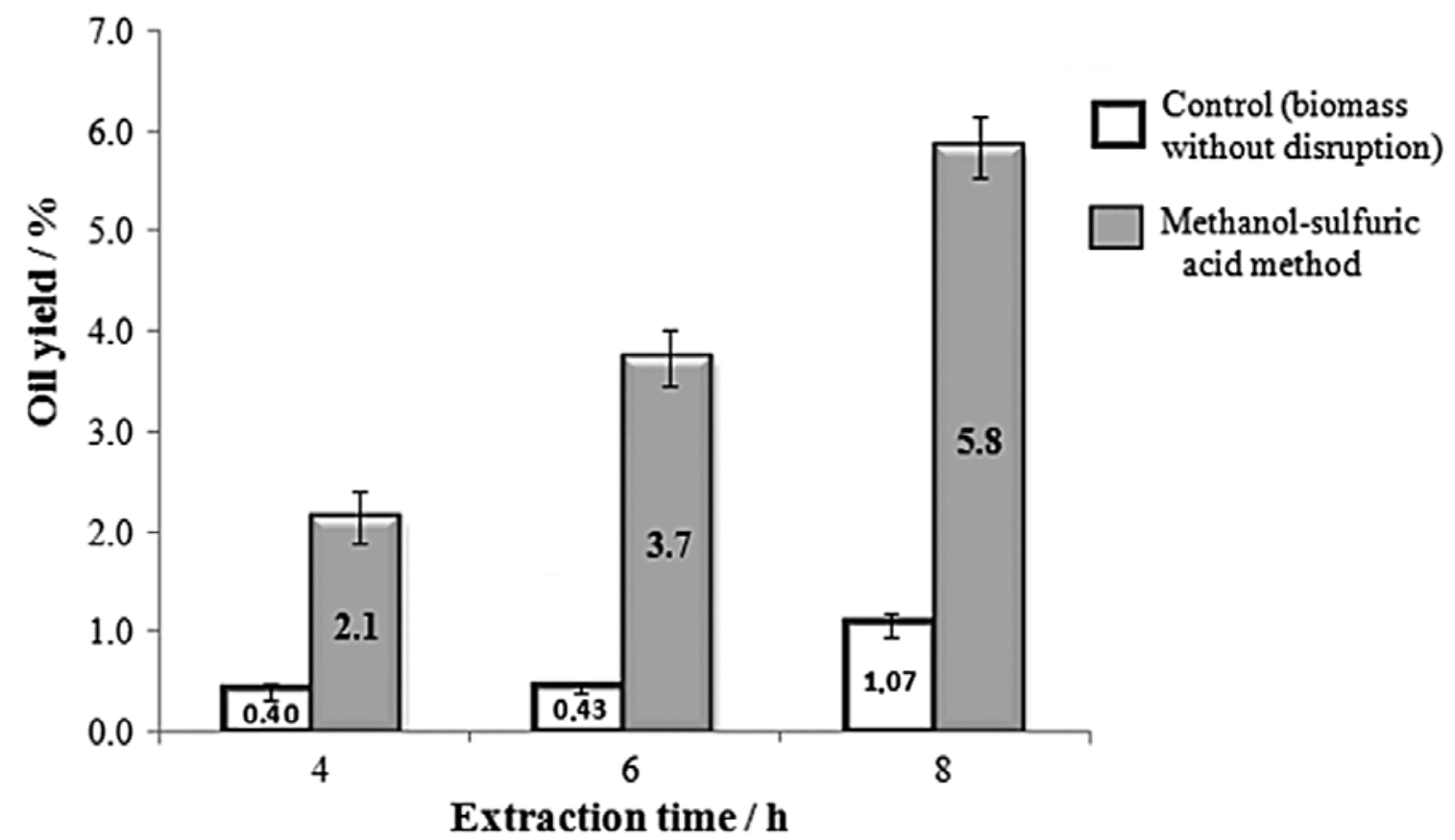

Fig. 4 Effect of extraction time on microalgae oil yield. 
TABLE III.

LIPID EXTRACTION EFFICIENCY IN RELATION TO OPERATION TIME

\begin{tabular}{l|c|c|c}
\multicolumn{1}{c|}{ Celldisruptionmethod } & $\begin{array}{c}\text { Extraction } \\
\text { time (h) }\end{array}$ & $\begin{array}{c}\text { Extractionefficiency } \\
(\%)\end{array}$ & $\begin{array}{c}\text { Standard } \\
\text { deviations }\end{array}$ \\
\hline \multirow{3}{*}{ Control } & 4 & 3.7 & 0.8325 \\
& 6 & 3.9 & 0.3648 \\
& 8 & 9.8 & 0.9874 \\
\hline MSA & 4 & 19.6 & 2.3862 \\
& 6 & 34.3 & 2.5732 \\
\hline
\end{tabular}

\section{Best experimental conditions obtained}

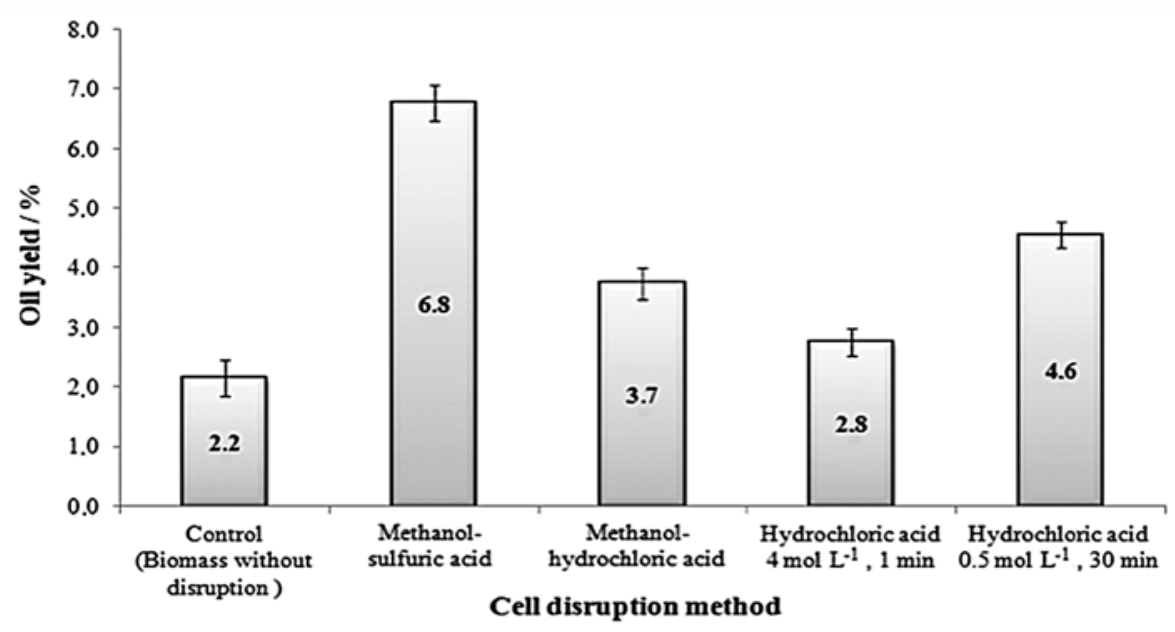

Fig. 5 Results obtained with the best conditions for the three genera of microalgae.

TABLE IV.

OIL EXTRACTION EFFICIENCY WITH THE BEST CONDITIONS FOUND

\begin{tabular}{l|c|c}
\multicolumn{1}{c|}{ Strain } & Extraction efficiency (\%) & Standard deviation \\
\hline Amphiprora & 56.5 & 2.5495 \\
\hline Desmodesmus & 53.6 & 2.7439 \\
\hline Tetraselmis & 57.6 & 1.8656 \\
\hline
\end{tabular}

aExperimental conditions: Biomass pretreated with methanol-sulfuric acid cell disruption method, and lipids were extracted with hexane solvent and extraction time was eight hours.

\section{E. Characterization of extracts}

As shown in Table 5 extracts obtained from biomass with methanol-sulfuric acid as cell disruption method, presents a higher content of saturated fatty acids, these are preferable in the production of biodiesel because prevent oxidation during storage. 
TABLE V.

Fatty Acid Composition Of Extracts Obtained (Percentage Of Total Fatty Acid).

\begin{tabular}{l|c|c|c|c|c|c|}
\hline Fatty acid (\%) & $\begin{array}{c}\text { Desmodes- } \\
\text { mus }^{\mathbf{a}}\end{array}$ & $\begin{array}{c}\text { Desmodes- } \\
\text { mus }^{\mathbf{b}}\end{array}$ & $\begin{array}{c}\text { Amphipro- } \\
\text { ra }^{\mathbf{a}}\end{array}$ & $\begin{array}{c}\text { Amphipro- } \\
\text { ra }^{\mathbf{c}}\end{array}$ & Amphiprora $^{\mathbf{b}}$ & $\begin{array}{c}\text { Amphipro- } \\
\text { rad }^{\mathbf{d}}\end{array}$ \\
$\begin{array}{l}\text { Total of the main } \\
\text { saturated } \\
\text { fatty acids }\end{array}$ & 7.4 & 48.3 & 24.1 & 22.6 & 27.3 & 21.4 \\
\hline $\begin{array}{l}\text { Total of the main } \\
\text { unsaturated } \\
\text { fatty acids }\end{array}$ & 90.3 & 47.8 & 70.5 & 66.8 & 58.1 & 65.8 \\
\hline $\begin{array}{l}\text { Total others } \\
\text { (saturatedand } \\
\text { unsaturated) }\end{array}$ & 2.3 & 3.9 & 5.4 & 10.6 & 14.6 & 12.8 \\
\hline
\end{tabular}

aBiomass without disruption (control), hexane, and extraction time was eight hours.

${ }^{\mathrm{b} M S A}$, hexane, eight hours.

'HA4M Fast, hexane, eight hours.

dMHA, hexane, eight hours.

eSaturated fatty acids: C10:0, C11:0, C12:0, C13:0, C14:0, C15:0, C16:0, C11:0, C18:0, C20:0

'unsaturated fatty acids: C14:1n-5, C15:1n-10c, C16:1, C18:1, C18:1n-9t, C18:2,C18:2n-9,12t, C20:2n-11,14c,C22:2, C18:3 n-6, C18:3, C20:3, C24:1

Besides as shown in Table 6 these extracts favorable for the extraction of lipids used in the have a higher estimated total of acylglycerols, biodiesel production, because the total amount they are who participate in the transesterifica- of acylglycerols is higher considering the total tion reaction. Therefore, cell disruption is more extracts obtained.

TABLE VI.

ESTIMATED TOTAL OF ACYLGLYCEROLS OF EXTRACTS OBTAINED.

\begin{tabular}{|c|c|c|c|}
\hline Experimental conditions & $\begin{array}{c}\text { Extracts } \\
\text { obtained(g) }\end{array}$ & $\begin{array}{c}\text { Acylglycerol } \\
\text { (\% area) }\end{array}$ & $\begin{array}{l}\text { Estimated total of } \\
\text { acylglycerols(g) }\end{array}$ \\
\hline Desmodesmus, control,hexane, $8 \mathrm{~h}$ & 0.0539 & 28.9 & 0.0156 \\
\hline \multicolumn{4}{|l|}{$\mathrm{H} 2 \mathrm{SO} 4$, hexano, $8 \mathrm{~h}$} \\
\hline Desmodesmus, MSA, hexane,8 h & 0.4413 & 24.7 & 0.1090 \\
\hline Amphiprora, control,hexane, $8 \mathrm{~h}$ & 0.1090 & 7.5 & 0.0082 \\
\hline Amphiprora, HA4M Fast, hexane, $8 \mathrm{~h}$ & 0.1614 & 7.4 & 0.0119 \\
\hline Amphiprora,MSA, hexane, $8 \mathrm{~h}$ & 0.5024 & 6.5 & 0.0327 \\
\hline Amphiprora,MHA, hexane, $8 \mathrm{~h}$ & 0.2672 & 7.1 & 0.0190 \\
\hline
\end{tabular}




\section{Conclusions}

The results obtained allowed to establish a set of experimental conditions favorable for microalgae oil extraction combining laboratory scale cell disruption and Soxhlet extraction method. The results also corroborate that the addition of a step of cell disruption before extraction process increases the efficiency of lipid extracted from microalgae, and the cell disruption method methanol-sulfuric acid $(56.5 \%)$ was the most efficient methods evaluated. In addition, in extraction of lipids from microalgae using Soxhlet extraction were obtained the higher oil yield using hexane solvent $(6.8 \%)$ and an operating time of eight hours $(5.8 \%)$ these conditions increased significantly the efficiency of the process $(56.5 \%$ and $53.6 \%$ respectively).

Furthermore, using the best experimental conditions, the extraction efficiency was over $50 \%$ for the three genera of microalgae used (Amphiprora: 56.5\%; Desmodesmus: $53.6 \%$ and Tetraselmis: $57.6 \%$ ) and within them, Tetraselmissp. shown the highest efficiency according to the oil yield.

\section{AcknOWLEDGments}

The authors thank the Ministry of Agriculture and Rural Development for their support through the project Bioprospecting of Colombian microalgae for biodiesel production code 2008D320066710, the Colombian Petroleum Institute (ICPECOPETROL), the Department of Science, Technology and Innovation COLCIENCIAS, and the Institute Morrosquillo.

\section{References}

[1] T. Koizumi, "Biofuels and food security," Renew Sustain Energy Rev, vol. 52, pp. 829-841, Dec. 2015.

[2] O. K. Lee, D. H. Seong, C. G. Lee, and E. Y. Lee, "Sustainable production of liquid biofuels from renewable microalgae biomass," J Ind Eng Chem, vol. 29, pp. 24-31, Apr. 2015.

[3] M. Guo, W. Song, and J. Buhain, "Bioenergy and biofuels: History, status, and perspective," Renew Sustain Energy Rev, vol. 42, pp. 712-725, Feb. 2015.

[4] Á.-D. González-Delgado, A.-F. Barajas-Solano, and V. Kafarov, "Obtención de productos de alto valor agregado en una topología de biorefinería utilizando microalgas," CT\&F - Ciencia, Tecnol y Futur, vol. 5, no. 3, pp. 95-106, 2013.

[5] Á. D. González-Delgado and V. Kafarov, "Design of a multifunctional reactor for third generation biofuels production," Chem Eng Trans, vol. 21, pp. 1297-1302, 2010.

[6] Á.-D. González-Delgado and V. Kafarov, "Microalgae Based Biorefinery: Evaluation of Several Routes for Joint Production of Biodiesel, Chlorophylls, Phycobiliproteins, Crude Oil and Reducing Sugars," Chem Eng Trans, vol. 29, no. 1, pp. 607-612, 2012.

[7] Á. D. González-Delgado and V. Kafarov, "Design and adjustment of coupled microalgae oil extraction methods for the developmentof a topology of biorefinery," Prospectiva, vol. 10, no. 1, pp. 113-123, 2012.

[8] K. Ramluckan, K. G. Moodley, and F. Bux, "An evaluation of the efficacy of using selected solvents for the extraction of lipids from algal biomass by the soxhlet extraction method," Fuel, vol. 116, pp. 103-108, Jan. 2014.

[9] C. L. Teo and A. Idris, "Enhancing the various solvent extraction method via microwave irradiation for extraction of lipids from marine microalgae in biodiesel production.," Bioresour Technol, vol. 171, pp. 477-81, Nov. 2014.

[10] D. Hernández, M. Solana, B. Riaño, M. C. GarcíaGonzález, and A. Bertucco, "Biofuels from microalgae: lipid extraction and methane production from the residual biomass in a biorefinery approach.," Bioresour Technol, vol. 170, pp. 370-8, Oct. 2014.

[11] Z. Li, K. H. Smith, and G. W. Stevens, "The use of environmentally sustainable bio-derived solvents in solvent extraction applications-a review," Chinese $J$ Chem Eng, Aug. 2015.

[12] F. Donot, G. Cazals, Z. Gunata, D. Egron, J. Malinge, C. Strub, A. Fontana, and S. Schorr-Galindo, "Analysis of neutral lipids from microalgae by HPLC-ELSD and APCI-MS/MS.," J Chromatogr B Analyt Technol Biomed Life Sci, vol. 942-943, pp. 98-106, Dec. 2013. 
